\title{
The Coupling Relationship between Economic Growth and Energy Consumption of Manufacturing in Tianjin
}

\author{
Quantitative analysis based on Tapio indicators
}

\author{
Ma Tao \\ College Of Economics \\ Tianjin Polytechnic University \\ Tianjin, China
}

\author{
Ye Xiaohan \\ College Of Economics \\ Tianjin Polytechnic University \\ Tianjin, China \\ 907911750@qq.com
}

\begin{abstract}
To analyze the progress of "Green Development" of Tianjin Manufacturing, this paper uses Tapio index to quantitatively analyze the coupling relationship between economic growth and energy consumption of Tianjin manufacturing. By decoupling the concept of elasticity, the different values of elasticity show the relevance of economic growth and energy consumption data and interactive situation. The conclusion of this paper is that during the period of "11th Five-year Plan", the Tianjin economic growth over the total energy consumption of the whole manufacturing dependent decrease slightly, but not too much, and the decoupling relationship is in a state of weak decoupling mostly, no qualitatively changes.
\end{abstract}

Keywords—Economic Growth; Energy Consumption; Tapio

\section{INTRODUCTION (HEADING 1)}

In 2005, foreign scholars Tapio p. (2005) published a article about decoupling problem of Europe's transportation energy and carbon dioxide. According to the size of the elasticity, Tapio decoupling can be divided into coupling, decoupling and negative decoupling and eight indicators [1]. By using the concept of Decoupling elasticity, it shows the connection and the interactions between data more clearly, according to the different elasticity values. Tapio defined decoupling elasticity as:

$M=\frac{\text { Environmental pressure changing rate }(\%)}{\text { Economic driving force } \operatorname{changing} \text { rate }(\%)}=\frac{\frac{E P_{t}-E P_{t-1}}{E P_{t-1}}}{\frac{E D_{t}-E D_{t-1}}{E D_{t-1}}}$

Among them, the $\mathrm{M}$ is for Decoupling coefficient of elasticity. $E P_{t}$ is for environmental pressure of $\mathrm{t}$ years, and $E P_{t-1}$ is for environmental pressure of $\mathrm{t}-1$ years. $E D_{t}$ is for economic driving force of $\mathrm{t}$ year, and $E D_{t-1}$ is for economic driving force of $\mathrm{t}-1$ year.

This paper is sponsored by 《The Countermeasure Research Of Tianjin Manufacturing Transformation and Upgrading promoted by Green Production under<made-in-china 2025> 》（15ZLZLZF00980）.

\section{A. Class 1:coupling}

Tapio suggests that changes between environmental pressure and economic driving force within the scope of the change of $1.0 \pm 20 \%$, therefore, decoupling between the elasticity value of environmental pressure and economic driving force within the scope of 0.8 to 1.2, and further can be divided into Expansive coupling and Recessive decoupling [2]

- Index 1: Expansive coupling. Expansive coupling is that the environmental pressure index and economic driving force index both are a positive growth, and located in the first I quadrant.

- Index 2:Recessive decoupling. Recessive decoupling is that the environmental pressure index and economic driving force index both are a negative growth, and located in the third III quadrant [3].

\section{B. Class 2:Decoupling}

- Index 3:Weak decoupling. Weak decoupling is that environmental pressure index and economic driving force index are increased, but compared with growth rate of environmental pressure index , the growth rate of economic driving force index is more quickly $(0<$ Value Of Elasticity $<0.8$ ), located in the first quadrant.

- Index 4:Strong decoupling. Strong decoupling is that economic driving force index increased, at the same time, environmental pressure index decreased. It is the ideal situation among eight indexes, and located in the fourth IV quadrant.

- Index 5:Recessive decoupling. Recessive decoupling is that environmental pressure index and economic driving force index are a negative growth, and the speed of environmental pressure reduce is greater than the economic driving force. 


\section{Class 3:Negative decoupling}

- Index 6:Expansive negative coupling. Expansive negative coupling is that environmental pressure index and economic driving force index are increased, and the increasing speed of environmental pressure index is greater than the economic driving force index (Value Of Elasticity $>1.2$ ), located in the first I quadrant.

- Index 7:Strong negative coupling. Strong negative coupling is that economic driving force index reduced, and environmental pressure index increased (Value Of Elasticity $<0$ ). It is the worst situation among eight indexes, located in the second $I$ I quadrant.

- Index 8:Weak negative decoupling. Weak negative decoupling is that Environmental pressure index and economic driving force index are reduced, but the speed of economic driving force index reduce is fast than the speed of environmental pressure reduce $(0<$ Value Of Elasticity $<0.8$ ), located in the thirdI quadrant.

II. THE COUPLING RELATIONSHIP BETWEEN ECONOMIC GROWTH AND ENERGY CONSUMPTION OF TIANJIN MANUFACTURINC

This paper used the energy consumption of Tianjin manufacturing(EC) to represent environmental pressure, and used the industrial value-added(GDP) to represent economic driving force. So coupling can be divided into eight kinds, just as TABLE I .

TABLE I. THE KIND OF TAPIO ELASTICITY

\begin{tabular}{|c|c|c|}
\hline Variation & $\mathbf{M}$ & kind \\
\hline $\begin{array}{l}\triangle \mathrm{GDP}>0 \\
\triangle \mathrm{EC}<0\end{array}$ & $\mathrm{M}<0$ & $\begin{array}{l}\text { Strong } \\
\text { decoupling }\end{array}$ \\
\hline \multirow{3}{*}{$\begin{array}{l}\triangle \mathrm{GDP}>0 \\
\triangle \mathrm{EC}>0\end{array}$} & $0 \leqq \mathrm{M} \leqq 0.8$ & $\begin{array}{l}\text { Weak } \\
\text { decoupling }\end{array}$ \\
\hline & $0.8<\mathrm{M} \leqq 1.2$ & $\begin{array}{l}\text { Expansive } \\
\text { coupling }\end{array}$ \\
\hline & $\mathrm{M}>1.2$ & $\begin{array}{l}\text { Expansive } \\
\text { negative } \\
\text { coupling }\end{array}$ \\
\hline $\begin{array}{l}\triangle \mathrm{GDP}<0 \\
\triangle \mathrm{EC}>0\end{array}$ & $\mathrm{M}<0$ & $\begin{array}{l}\text { Strong negative } \\
\text { coupling }\end{array}$ \\
\hline \multirow{3}{*}{$\begin{array}{l}\triangle \mathrm{GDP}<0 \\
\triangle \mathrm{EC}<0\end{array}$} & $0 \leqq \mathrm{M} \leqq 0.8$ & $\begin{array}{l}\text { Weak negative } \\
\text { decoupling }\end{array}$ \\
\hline & $0.8<\mathrm{M} \leqq 1.2$ & $\begin{array}{l}\text { Recessive } \\
\text { decoupling }\end{array}$ \\
\hline & $\mathrm{M}>1.2$ & $\begin{array}{l}\text { Recessive } \\
\text { decoupling }\end{array}$ \\
\hline
\end{tabular}

The data of this section is coming from Tianjin statistical yearbook of 1999-2010[4]. (this section delete the data of "resource waste and old materials recycling industry" , because it is incomplete. The energy consumption contains the consumption of coal, gasoline, diesel and electricity.) Owing to the empty of the industrial value-added in 2009 and 2010, we used nonlinear fitting between years and the industrial value-added in 1999 to 2008 with aid of SPSS17.0. The result can be presented by Equation (2).

$$
\mathrm{GDP}=3082322.91 * \mathrm{EXP}[0.216(\text { YEARS-1998)] }
$$

To make a statistical analysis of this result, we can come TABLE II and TABLE IV.

TABLE II. THE MODEL OF REGRESSION EQUATION

\begin{tabular}{|l|l|l|}
\hline $\begin{array}{c}\text { correlation } \\
\text { coefficient }\end{array}$ & $\begin{array}{c}\text { Coefficient of } \\
\text { determination }\end{array}$ & $\begin{array}{c}\text { Correct determination } \\
\text { coefficient }\end{array}$ \\
\hline 0.997 & 0.994 & 0.993 \\
\hline
\end{tabular}

As is shown in Table II , coefficient of determination is 0 . 994. It means that there is a relative link between the industrial value-added and year, which conform to the reality.

TABLE III. THE SIGNIFICANCE TEST OF REGRESSION EQUATION

\begin{tabular}{|c|l|l|l|}
\hline name & $\begin{array}{c}\text { Regression } \\
\text { Sum of } \\
\text { Squares }\end{array}$ & $\begin{array}{c}\text { Residual } \\
\text { Sum of } \\
\text { Squares }\end{array}$ & $\begin{array}{l}\text { Total sum } \\
\text { of square }\end{array}$ \\
\hline Sum of Squares & 3.857 & 0.023 & 3.88 \\
\hline $\begin{array}{c}\text { degree of } \\
\text { freedom }\end{array}$ & 1 & 8 & 9 \\
\hline $\begin{array}{c}\text { mean square } \\
\text { deviation }\end{array}$ & 3.857 & 0.003 & \\
\hline F & 1332.491 & \multicolumn{2}{|l|}{} \\
\hline$P$ & 0.001 &
\end{tabular}

From Table III, probability value is 0.001 , less than 0.05 . It means that this result has statistical significance.

TABLE IV. THE SIGNIFICANCE TEST OF REGRESSION EQUATION COEFFICIENT

\begin{tabular}{|c|c|c|c|}
\hline \multicolumn{2}{|c|}{ model } & $c$ & years \\
\hline \multirow{2}{*}{$\begin{array}{c}\text { Not } \\
\text { standardized } \\
\text { parameters }\end{array}$} & Parameter B & 3082322.91 & 0.216 \\
\hline & $\begin{array}{c}\text { standard } \\
\text { error }\end{array}$ & 113280.242 & 0.006 \\
\hline \multicolumn{2}{|c|}{$\begin{array}{c}\text { After the standardization of } \\
\text { parameters }\end{array}$} & & 0.997 \\
\hline \multicolumn{2}{|c|}{$\mathbf{t}$} & 27.503 & 27.21 \\
\hline \multicolumn{2}{|c|}{$\mathbf{P}$} & 0.001 & 0.001 \\
\hline
\end{tabular}

We know from Table IV that probability value is 0.001 , less than 0 . 05. It means that nonlinear regression equation between years and the industrial value-added is significant.

According to Equation (2), we can work out that the industrial value-added of 2009 is 331.712489 billion yuan, and the industrial value-added of 2010 is 411.6891592 billion yuan respectively. We can draw scatter diagram about the energy consumption of Tianjin manufacturing from 1999 to 2010 and the industrial value-added of Tianjin manufacturing from 1999 to 2010. 


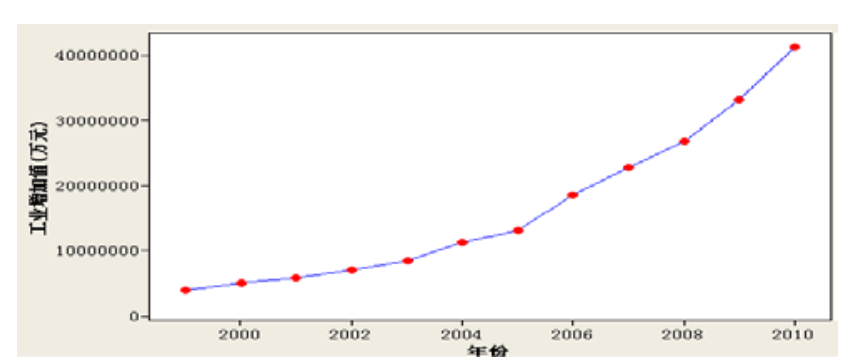

Fig. 1. the energy consumption of Tianjin manufacturing from 1999 to 2010

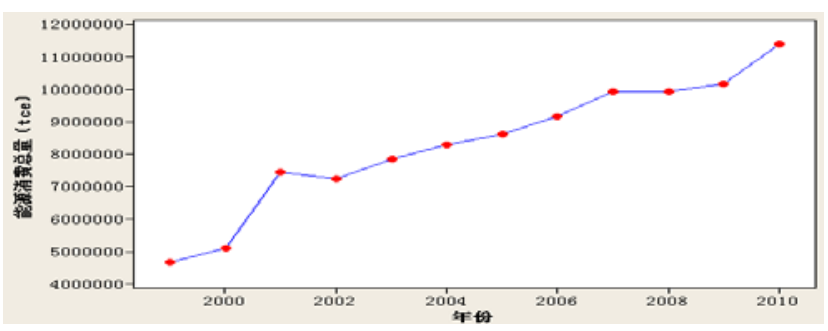

Fig. 2. the industrial value-added of Tianjin manufacturing from 1999 to 2010

As is shown in Table V, Then using Equation (1) and two data sets above, we can work out the coupling relationship between economic growth and energy consumption of Tianjin manufacturing.

TABLE V. HE COUPLING RELATIONSHIP BETWEEN ECONOMIC GROWTH AND ENERGY CONSUMPTION OF TIANJIN MANUFACTURING

\begin{tabular}{|l|l|l|l|l|}
\hline years & $\begin{array}{c}\text { the industrial } \\
\text { value-added } \\
\text { (ten thousands } \\
\text { yuan) }\end{array}$ & EC(tce) & $\begin{array}{c}\text { the coupling } \\
\text { elasticity }\end{array}$ & $\begin{array}{l}\text { The type of } \\
\text { the coupling }\end{array}$ \\
\hline 2000 & 5009366 & 5083980.86 & 0.359705 & $\begin{array}{l}\text { Weak } \\
\text { decoupling }\end{array}$ \\
\hline 2001 & 5800959 & 7445120.10 & 2.938993 & $\begin{array}{l}\text { expansive } \\
\text { negative } \\
\text { coupling }\end{array}$ \\
\hline 2002 & 7007744 & 7228769.92 & -0.13969 & $\begin{array}{l}\text { Strong } \\
\text { decoupling }\end{array}$ \\
\hline 2003 & 8445955 & 7848810.75 & 0.417938 & $\begin{array}{l}\text { Weak } \\
\text { decoupling }\end{array}$ \\
\hline 2004 & 11149197 & 8293357.37 & 0.176961 & $\begin{array}{l}\text { Weak } \\
\text { decoupling }\end{array}$ \\
\hline 2005 & 13115693 & 8617839.32 & 0.221825 & $\begin{array}{l}\text { Weak } \\
\text { decoupling }\end{array}$ \\
\hline 2006 & 18523889 & 9161674.66 & 0.153041 & $\begin{array}{l}\text { Weak } \\
\text { decoupling }\end{array}$ \\
\hline 2007 & 22703803 & 9946592.98 & 0.379677 & $\begin{array}{l}\text { Weak } \\
\text { decoupling }\end{array}$ \\
\hline 2008 & 26779875 & 9939343.99 & -0.00406 & $\begin{array}{l}\text { Strong } \\
\text { decoupling }\end{array}$ \\
\hline 2009 & 33171249 & 10166682.03 & 0.095836 & $\begin{array}{l}\text { Weak } \\
\text { decoupling }\end{array}$ \\
\hline 41168916 & 11396387.50 & 0.501673 & $\begin{array}{l}\text { Weak } \\
\text { decoupling }\end{array}$ \\
\hline
\end{tabular}

\section{CONCLUSION}

As is shown in Graph V, the growth rate of the industrial value-added of Tianjin manufacturing from 1999 to 2010 is positive value. Except for 2002 and 2008, the growth rate of the energy consumption of Tianjin manufacturing is positive value, which is less than the growth rate of GDP. By observing decoupling flexibility and decoupling relationship, for the reason that the growth rate of the industrial valueadded is far less than the growth rate of energy consumption in 2000 and 2001, the type of coupling in 2001 is expansive negative coupling. In 2002 and 2008, the fact that the growth rate of the industrial value-added is positive value, but the industrial value-added is reducing, leads to the result that the type of coupling is strong decoupling. It is the ideal situation. the growth rate of the industrial value-added and comprehensive energy consumption in the rest of the years has been in a relatively stable range. The type of coupling in these years is always weak decoupling. The decoupling flexibility is stable. During the period of "11th Five-year Plan", the Tianjin economic growth over the total energy consumption of the whole manufacturing dependent decrease slightly, but not too much, and the decoupling relationship is in a state of weak decoupling mostly, no qualitatively changes.

\section{References}

[1] Wanglei,”Reduce Material Model Research to Binhai new area”, FORUM ON SCIENCE AND TECHNOLOGY IN CHINA, 2012(6), $79-86$.

[2] Liu Yijun, Wangli, Niu Wenyuan.”The decoupling analysis of Chinese urban economic development and energy consumption” , China Population Resources and Environment, 2011(1), 70-77.

[3] Renjing. The Coupling Relationship between Social economic development and Carbon emission in Henan province, Zhengzhou University, 2012.

[4] Yin Yanbing, Yangxue. The Coupling Relationship between technical innovation and energy consumption of manufacturing, SCIENCE AND TECHNOLOGY MANAGEMENT RESEARCH, 2010(6), 231-235, 241. 